\title{
Field application of Trichoderma spp. combined with thiophanate-methyl for controlling Fusarium solani and Fusarium oxysporum in dry bean
}

\author{
H. Abd-El-Khair ${ }^{1}$, I. E. Elshahawy ${ }^{1 *}$ and H. E. Karima Haggag ${ }^{2}$
}

\begin{abstract}
Background: Damping-off and root rot/wilt diseases caused by the soil-borne fungi Fusarium solani and F. oxysporum are a serious problem of dry bean productions in Egypt. This study examines the potential of controlling these diseases biologically by using three Trichoderma isolates, compatible with the fungicide thiophanatemethyl, i.e., T. harzianum, $T$. viride, and T. virens. Soil application with inoculants containing these isolates employed either alone or in combination with seed coating with thiophanate-methyl was applied.

Results: Under greenhouse and field conditions, all treatments significantly reduced the incidence of damping-off and root rot/wilt diseases and increased the percentage of survival plants. These treatments increased vegetative growth parameters and yield components of the survival dry bean plants compared with untreated control. Soil application with Trichoderma isolates combined with thiophanate-methyl seed treatments was more effective than using both of them individually. Meanwhile, T. virens + thiophanate-methyl was the most effective treatment. The tested treatments stimulated systemic defense responses in dry bean plants by activating defense enzymes including peroxidase, polyphenoloxidase, and chitinase.

Conclusions: Based on the obtained results, compatible isolates of Trichoderma spp. as soil treatment combined with thiophanate-methyl as seed treatment may have potential to develop a new biofungicide for integrated management of damping-off and root rot/wilt diseases in dry bean.
\end{abstract}

Keywords: Trichoderma spp., Compatible isolates, Thiophanate-methyl, Damping-off and root rot/wilt, Dry bean

\section{Background}

Dry bean (Phaseolus vulgaris L.) is one of the most important food legumes for human consumption in the world. Several soil-borne fungi attacked bean plants causing damping-off and root rot/wilt diseases. These diseases were commonly attributed to Fusarium solani (Mart.) Sacc. in complex with Rhizoctonia solani and F. oxysporum (Abdel-Kader 1997; Estevez de Jensen et al. 1999, 2002). The disease incidence of damping-off and bean root rot has risen with the increased acreage of this crop, the shortening of crop rotation intervals, and the use of

\footnotetext{
*Correspondence: ibrahim_nrc@yahoo.com

${ }^{1}$ Plant Pathology Department, Agricultural and Biological Research Division, National Research Centre, Giza, Egypt

Full list of author information is available at the end of the article
}

highly susceptible cultivars. Yield losses in several infested areas approach 50\% (Estevez de Jensen et al. 2002). Biocontrol treatment with certain strains of Trichoderma spp. can be used for controlling several soil-borne diseases such as damping-off, root-rot, and wilt (El-Nagdi and Abd-El-Khair 2014; Woo et al. 2014; Elshahawy et al. 2017a, 2017b). Biological control methods are safe and environmentally friendly pesticide alternatives in agriculture application (Elshahawy et al. 2017c). But biological control alone is sometimes un-sufficient to eradicate or reduce the propagules of the pathogens. Therefore, integration methods between biocontrol agents and the fungicides could be effective. The tolerance of several biocontrol agents to fungicides was studied by many workers over the world (Howell et al. 1997; Wang et al. 2005; Howell 
2007; Vasundara et al. 2015; Khalequzzaman 2016). In a previous study, we investigated in vitro the compatibility of ten Trichoderma spp. isolates (three of T. harzianum, three of $T$. viride, one of $T$. virens, and three of Trichoderma spp.) with seven fungicides viz., carbendazim, flutolanil, mancozeb, metalaxyl $\mathrm{M}+$ mancozeb, pencycuron, thiram + tolclofos-methyl, and thiophanatemethyl (Elshahawya et al. 2016). The results of our investigations revealed that each of flutolanil, pencycuron, and thiophanate-methyl when separately combined with Trichoderma spp. isolates reduced the growth of the tested soil-borne pathogens in the ranges of $22.2-100 \%$, $43.7-100 \%$, and $50.4-100 \%$, compared to the reduction of $0.0-21.1 \%, 0.0-18.9 \%$, and $15.6-18.9 \%$ resulted by the same fungicides when used alone, respectively. Our results suggested that the fungicides-Trichoderma spp. isolate combination may be effective in controlling soil-borne pathogenic fungi than individual treatment and reduced the amount of fungicide used. The results of our investigations revealed that Trichoderma spp. were highly compatible with thiophanate-methyl. Therefore, this work is amid to study the effects of Trichoderma spp. combined with thiophanate-methyl for controlling damping-off and root rot/wilt diseases of bean caused by $F$. solani and F. oxysporium in a greenhouse and in field experiments.

\section{Materials and methods}

\section{Plant materials and fungicide}

Bean seeds cv. Giza 4 was obtained from the Agricultural Research Centre (ARC), Egypt. The fungicide Thiophanatemethyl (Topsin - M 70\% WG) was obtained from the Central Agricultural Pesticides Laboratory (CAPL), ARC, Egypt.

\section{Pathogens}

The soil-borne pathogens viz. F. solani and F. oxysporum which are considered the most virulent pathogens causing damping-off and root-rot/wilt diseases were obtained from the Plant Pathology Department, National Research Centre (NRC), Egypt. Pathogenic ability of these isolates toward dry bean was confirmed in a previous study (Abd-El-Khair and El-Gamal Nadia 2011). Fungal mass production used for soil infestation in greenhouse experiment was obtained by growing the tested isolates on sand-barley medium. This natural medium was prepared by mixing sand and barley (1:1, w:w and $40 \%$ water); then the mixture in glass bottles with cotton plugs was sterilized. The autoclaved medium was then inoculated individually with a 5 -mm disk of each tested fungal isolate and incubated at $25 \pm 2{ }^{\circ} \mathrm{C}$ for 2 weeks (Singleton et al. 1992).

\section{Trichoderma spp.}

Three isolates of Trichoderma harzianum, T. viride, and T. virens obtained from the Plant Pathology Department,
National Research Centre, Egypt were used in this study. The compatibility of these isolates with thiophanate-methyl was confirmed in the previous study (Elshahawya et al. 2016). Fungal mass production used for soil treatment in greenhouse and field experiments was obtained by growing the tested isolates on sand-corn medium. This natural medium was prepared by mixing sand and corn (1:1, w: $w$ and $40 \%$ water); then the mixture in glass bottles with cotton plugs was sterilized. The autoclaved medium was then inoculated individually with a 5 - $\mathrm{mm}$ disk of each tested fungal isolate and incubated at $25 \pm 2{ }^{\circ} \mathrm{C}$ for 2 weeks.

\section{Greenhouse experiment}

The experiment was conducted to assess the effect of soil treatment with each of Trichoderma harzianum, $T$. viride, and $T$. virens, combined with seed coating with thiophanate-methyl on pre- and post-emergence damping-off and root rot/wilt of bean caused by $F$. solani and $F$. oxysporum in pots. These experiments were carried out in potted soils under greenhouse conditions located at the Pest Rearing Department, CAPL, ARC, Giza, Egypt, following the soil infestation technique. Autoclaved sandy loamy soil was used. Formalin-sterilized plastic pots (30-cm diameter) were filled with $5 \mathrm{~kg}$ of autoclaved sandy loamy soil infested with the inocula of each of $F$. solani and $F$. oxysporum at the rate of $4 \%(w: w)$. The inoculum of each of Trichoderma harzianum, $T$. viride, and $T$. virens was added (at the rate of $1 \% w / w)$ to the infested soil 1 week later. Un-amended infested pots were used as control. One week later, dry bean seeds were sown. Bean seeds cv. Giza 4 were surface disinfected in $3 \% \mathrm{NaOCl}$ for $3 \mathrm{~min}$, washed three times in sterile distilled water, and then left for $30 \mathrm{~min}$ at room temperature before treating with the desired fungicide. Bean seeds were then soaked for $15 \mathrm{~min}$ in $1 \%$ methyl cellulose $(\mathrm{MC})$ solution at the rate of $3 \mathrm{ml}$ per 100 seeds. Thereafter, bean seeds were removed and placed in plastic bags and coated with thiophanate-methyl at the rate of $1 \mathrm{~g}$ per $1 \mathrm{~kg}$ of seeds. Bags were inflated with air and shaken vigorously. Thereafter, seeds were directly planted in the infested-potted soil.

Five bean seeds cv. Giza 4 were sown in each pot. Three pots were used as replicates per each treatment as well as for the control (Abd-El-Khair et al. 2010).

The treatments were as follows:

\section{Experiment I}

1. F. solani + T. harzianum + thiophanate-methyl

2. F. solani + T. viride + thiophanate-methyl

3. F. solani + T. virens + thiophanate-methyl

4. F. solani + T. harzianum

5. F. solani + T. viride 
6. F. solani + T. virens

7. F. solani + thiophanate-methyl

8. F. solani only

\section{Experiment II}

1. F. oxysporum + T. harzianum + thiophanate-methyl

2. F. oxysporum + T. viride + thiophanate-methyl

3. F. oxysporum + T. virens + thiophanate-methyl

4. F. oxysporum + T. harzianum

5. F. oxysporum + T. viride

6. F. oxysporum + T. virens

7. F. oxysporum + thiophanate-methyl

8. F. oxysporum only

\section{Data recorded}

The incidence of pre- and post-emergence damping-off was recorded after 15 and 30 days of sowing, and the incidence of root rot/wilt was recorded up to 60 days of sowing. The percentages of survival bean plant and the growth parameters of bean such as averages of root length $(\mathrm{cm})$, shoot length $(\mathrm{cm})$, leaves number per plant, plant fresh weight $(\mathrm{g})$, and plant dry weight $(\mathrm{g})$ were recorded.

\section{Field experiments}

Naturally infested soil with F. solani and F. oxysporum at El-Kantar El-Khairiya, Kalubeiya Governorate, Egypt, was chosen for estimating the efficiency of soil treatment with Tricoderma spp. combined with seed coating with thiophanate-methyl for controlling pre- and post-emergence damping-off and root rot/wilt of bean plants under field conditions. Field experiments were conducted during tow growth season of 2015 and 2016. The experiments were conducted with a completely randomized design (CRD) with eight treatments (T. harzianum + thiophanate-methyl, $T$. viride + thiophanate-methyl, $T$. virens + thiophanate-methyl, $T$. harzianum, $T$. viride, $T$. virens, thiophanate-methyl, and control) each with four experimental units. Experimental unit consisted of four rows. The dimensions of each row were $2 \mathrm{~m}$ in length, 50 $\mathrm{cm}$ in length, and $30 \mathrm{~cm}$ in height. The inoculum of each Tricoderma spp., freshly prepared, was incorporated to the soil at the rate of $300 \mathrm{~g}$ formulation/m length of the row. Therefore, a cavity of $15 \mathrm{~cm}$ in depth was made on the surface of each row. Then the inoculum was added to this cavity and then recovered with the soil and immediately irrigated. One week after incorporation, thiophanate-methyl coated and non-coated bean seeds were sown in holes at the rate of two seeds per hole. Irrigation and fertilization were conducted as generally recommended for bean production regimes.

\section{Data recorded \\ Damping-off and root rot/wilt incidence}

The incidence of pre- and post-emergence damping-off was recorded after 15 and 30 days of sowing, and the incidence of root rot/wilt was recorded up to 60 days of sowing.

\section{Determination of enzyme activities}

The effect of soil treatment with Tricoderma spp. combined with seed coating with thiophanate-methyl on the activities of the defense enzymes of peroxidase, polyphenoloxidase, and chitinase of bean plants was estimated at 60 days after planting under field conditions. To extract the enzyme, bean leaf samples (g) were homogenized with $0.2 \mathrm{M}$ Tris $\mathrm{HCl}$ buffer $(\mathrm{pH} 7.8)$ at $0{ }^{\circ} \mathrm{C}$ containing $14 \mathrm{~m} \mathrm{M} \mathrm{B-mercaptoethanol} \mathrm{at} \mathrm{the} \mathrm{rate} \mathrm{of} 1 / 3$ $w / v$. The extracts were obtained by filtering off the debris with a clean cloth and centrifuging at $3000 \mathrm{rpm}$ for $15 \mathrm{~min}$. The supernatants were recovered and kept in a tube in an ice bath until assayed. The supernatant was used to determine the activity of enzymes by using UV spectrophotometer. Peroxidase activity was assayed with guaiacol as the hydrogen donor as described by Hammerschmidt et al. (1984), and peroxidase activity was expressed as the increase in absorbance at $470 \mathrm{~nm} / \mathrm{g}$ fresh weight/min according to the method described by Lee (1973). Polyphenoloxidase enzyme activity was determined by measuring the rate of quinone formation as a result of oxidizing 3,4-dihydroxyphenylalanine (DOPA), and polyphenoloxidase activity was expressed as the increase in absorbance at $475 \mathrm{~nm} / \mathrm{g}$ fresh weight/ min according to the method described by Bashan et al. (1985). The determination of chitinase enzyme was carried out using colloidal chitin as substrate and dinitrosalicylic acid (DNS) as a reagent to measure reducing sugars according to the method described by Monreal and Reese (1969). Chitinase activity was expressed as $\mathrm{mM} \mathrm{N}$-acetyl glucose amine equivalent released/g fresh weight $/ 60 \mathrm{~min}$ at $540 \mathrm{~nm}$.

\section{Growth parameter and yield components}

The vegetative parameters viz., shoot fresh weight (g), and number of branches/plants as well as yield parameters viz., pod number, pod weight (g), weight of 100 seeds (g), and seeds weight (g) were recorded at harvest time.

\section{Statistical analysis}

Data were subjected to analysis of variance using Computer Statistical Package (CO-STATE) User Manual Version 3.03, Barkley Co., USA. Means of values were compared by the Least Significant Difference (LSD) test at $P \leq 0.05$ level of significance (Steel and Torrie 1980). 


\section{Results}

Greenhouse experiments

Effect of Trichoderma spp. and thiophanate-methyl on disease incidence

Data presented in Table 1 show that all treatments highly reduced damping-off and root rot/wilt incidence and increased survival plants of dry bean compared to untreated plants. Dry bean seeds coated with thiophanate-methyl combined with Trichoderma spp. soil treatment reduced damping-off and root rot/wilt incidence more than individual treatment. Trichoderma spp. were more effective to reduce damping-off and root rot/wilt than thiophanate-methyl. On the other hand, the combination of thiophanate-methyl $+T$. virens, thiophanate-methyl + $T$. harzianum, and thiophanate-methyl $+T$. viride recorded almost the same protection against to any of the tested fungi. In the case of Fusarium solani, the combined treatments recorded the lowest percentages of damping-off (by the range of 0.0 and $7.1 \%$ ), in comparison with 60.0 and $18.1 \%$ for the control. Root rot was also reduced to $7.1 \%$ in comparison with $33.3 \%$ for the control. In the case of Fusarium oxysporum, the combined treatments recorded the lowest percentages of damping-off (by the range of 7.1 and $7.7 \%$ ), in comparison with 53.3 and $28.6 \%$ for the control. Wilt incidence was also reduced to the same range in comparison with $42.9 \%$ for the control.

\section{Effect of Trichoderma spp. and thiophanate-methyl on vegetative growth parameters}

In the present study, Trichoderma spp. (T. harzianum, T. viride, and $T$. virens) and chemical fungicide (thiophanate-methyl) individually or in combination recorded significant highly increased vegetative growth parameters of bean plants in the presence of pathogenic fungi (Table 2). Trichoderma spp. combined with thiophanate-methyl increased vegetative growth parameters of bean plants more than using any of them individually in terms of root length $(\mathrm{cm})$, shoot length $(\mathrm{cm})$, number of leaves/plant, plant fresh weight (g), and plant dry weight (g). Also, Trichoderma spp. gave vegetative growth parameters higher than the usage of chemical fungicide. Generally, the combination of thiophanate-methyl $+T$. virens, thiophanatemethyl $+T$. harzianum, and thiophanate-methyl $+T$. viride recorded almost the same vegetative growth parameters of bean plants in infested soil with each of F. solani or F. oxysporum.

Table 1 Effect of soil application with Trichoderma spp. and seed coating with thiophanate-methyl employed either alone or in combination on damping-off, root rot/wilt, and survival dry bean plants grown in soil artificially infested with each of Fusarium solani and Fusarium oxysporum under greenhouse conditions

\begin{tabular}{|c|c|c|c|c|}
\hline \multirow[t]{3}{*}{ Treatment } & \multicolumn{4}{|l|}{ Fusarium solani } \\
\hline & \multicolumn{2}{|l|}{ Damping-off (\%) } & \multirow[t]{2}{*}{ Root rot (\%) } & \multirow[t]{2}{*}{ Survival plants (\%) } \\
\hline & Pre-emergence & Post-emergence & & \\
\hline Thiophanate-methyl $+T$. harzianum & 6.7 e & $7.1 \mathrm{e}$ & $7.1 \mathrm{e}$ & $85.8 \mathrm{~b}$ \\
\hline Thiophanate-methyl $+T$. viride & 6.7 e & 7.1 e & $7.1 \mathrm{e}$ & $85.8 \mathrm{~b}$ \\
\hline Thiophanate-methyl $+T$. virens & 6.7 e & $0.0 \mathrm{f}$ & $7.1 \mathrm{e}$ & 92.9 a \\
\hline T. harzianum & $20.0 \mathrm{c}$ & $8.3 \mathrm{c}$ & $8.3 c$ & $83.4 d$ \\
\hline T. viride & $13.3 \mathrm{~d}$ & $7.7 \mathrm{~d}$ & $7.7 d$ & $84.6 \mathrm{c}$ \\
\hline T. virens & $20.0 \mathrm{c}$ & $8.3 \mathrm{c}$ & $8.3 \mathrm{c}$ & $83.4 \mathrm{~d}$ \\
\hline Thiophanate-methyl & $26.7 \mathrm{~b}$ & $16.7 \mathrm{~b}$ & $9.1 \mathrm{~b}$ & 72.8 e \\
\hline Pathogen only & $60.0 \mathrm{a}$ & $18.1 \mathrm{a}$ & 33.3 a & $50.0 \mathrm{f}$ \\
\hline \multirow[t]{3}{*}{ Treatment } & \multicolumn{4}{|c|}{ Fusarium oxysporum } \\
\hline & \multicolumn{2}{|l|}{ Damping-off (\%) } & \multirow[t]{2}{*}{ Wilt (\%) } & \multirow[t]{2}{*}{ Survival plants (\%) } \\
\hline & Pre-emergence & Post-emergence & & \\
\hline Thiophanate-methyl $+T$. harzianum & $13.3 \mathrm{~d}$ & 7.7 e & $7.7 d$ & 84.4 b \\
\hline Thiophanate-methyl $+T$. viride & $13.3 \mathrm{~d}$ & 7.7 e & $7.7 d$ & $84.4 \mathrm{~b}$ \\
\hline Thiophanate-methyl $+T$. virens & 6.7 e & $7.1 \mathrm{f}$ & $7.1 \mathrm{e}$ & $85.8 \mathrm{a}$ \\
\hline T. harzianum & $20.0 \mathrm{c}$ & $9.1 \mathrm{c}$ & $8.3 c$ & $75.0 \mathrm{~d}$ \\
\hline T. viride & $20.0 \mathrm{c}$ & $8.3 \mathrm{~d}$ & $8.3 c$ & $83.4 \mathrm{C}$ \\
\hline T. virens & $20.0 \mathrm{c}$ & $8.3 \mathrm{~d}$ & $8.3 \mathrm{c}$ & $83.4 \mathrm{C}$ \\
\hline Thiophanate-methyl & $26.7 \mathrm{~b}$ & $16.7 \mathrm{~b}$ & $18.2 \mathrm{~b}$ & 72.7 e \\
\hline Pathogen only & $53.3 \mathrm{a}$ & $28.6 \mathrm{a}$ & 42.9 a & $28.5 f$ \\
\hline
\end{tabular}

The same letter after means in each column is not significantly different according to Duncan's multiple range test $(P=0.05)$ 
Table 2 Effect of soil application with Trichoderma spp. and seed coating with thiophanate-methyl employed either alone or in combination on vegetative growth parameter of dry bean plants grown in soil artificially infested with each of Fusarium solani and Fusarium oxysporum under greenhouse conditions

\begin{tabular}{|c|c|c|c|c|c|}
\hline \multirow[t]{3}{*}{ Treatment } & \multicolumn{5}{|c|}{ Average vegetative growth parameters of bean plants } \\
\hline & \multicolumn{5}{|l|}{ Fusarium solani } \\
\hline & Root length $(\mathrm{cm})$ & Shoot length $(\mathrm{cm})$ & No. of leaves/plant & Plant fresh weight (g) & Plant dry weight (g) \\
\hline Thiophanate-methyl + T. harzianum & $17.2 \mathrm{~b}$ & $43.7 \mathrm{~b}$ & $6.7 \mathrm{~b}$ & $15.2 \mathrm{~b}$ & $2.43 \mathrm{C}$ \\
\hline Thiophanate-methyl + T. viride & $16.5 \mathrm{c}$ & $44.0 \mathrm{~b}$ & $8.3 \mathrm{a}$ & $14.1 \mathrm{C}$ & $3.43 \mathrm{a}$ \\
\hline Thiophanate-methyl + T. virens & 19.7 a & $45.2 \mathrm{a}$ & $6.8 \mathrm{~b}$ & $16.4 \mathrm{a}$ & $2.98 \mathrm{~b}$ \\
\hline T. harzianum & 15.5 e & $43.0 \mathrm{C}$ & $5.7 d$ & $12.5 \mathrm{e}$ & $2.38 \mathrm{e}$ \\
\hline T. viride & $14.8 \mathrm{f}$ & $41.2 \mathrm{~d}$ & $5.7 d$ & $11.6 f$ & $1.95 f$ \\
\hline T. virens & $16.0 \mathrm{~d}$ & 39.8 e & $6.2 c$ & $12.7 \mathrm{~d}$ & $2.39 \mathrm{~d}$ \\
\hline Thiophanate-methyl & $14.0 \mathrm{~g}$ & $38.7 f$ & 5.5 e & $11.5 \mathrm{~g}$ & $1.94 \mathrm{~g}$ \\
\hline Pathogen only & $13.7 \mathrm{~h}$ & $33.3 \mathrm{~g}$ & $4.8 \mathrm{f}$ & $10.8 \mathrm{~h}$ & $1.55 \mathrm{~h}$ \\
\hline \multirow[t]{3}{*}{ Treatment } & \multicolumn{5}{|c|}{ Average vegetative growth parameters of bean plants } \\
\hline & \multicolumn{5}{|c|}{ Fusarium oxysporum } \\
\hline & Root length $(\mathrm{cm})$ & Shoot length $(\mathrm{cm})$ & No. of leaves /plant & Plant fresh weight (g) & Plant dry weight (g) \\
\hline Thiophanate-methyl + T. harzianum & $21.1 \mathrm{~b}$ & 43.7 a & $7.7 \mathrm{a}$ & $37.7 \mathrm{~b}$ & $5.35 \mathrm{a}$ \\
\hline Thiophanate-methyl $+T$. viride & $20.8 c$ & $41.2 \mathrm{C}$ & $7.3 \mathrm{~b}$ & $38.1 \mathrm{a}$ & $4.89 \mathrm{C}$ \\
\hline Thiophanate-methyl $+T$. virens & $21.3 \mathrm{a}$ & $42.2 \mathrm{~b}$ & $7.7 \mathrm{a}$ & $36.6 \mathrm{c}$ & $5.17 \mathrm{~b}$ \\
\hline T. harzianum & $18.7 \mathrm{e}$ & $42.0 \mathrm{~b}$ & $6.5 d$ & $25.1 \mathrm{f}$ & $4.63 d$ \\
\hline T. viride & $18.8 \mathrm{e}$ & $42.2 \mathrm{~b}$ & $6.8 c$ & 30.3 e & $4.05 f$ \\
\hline T. virens & $20.2 d$ & $41.2 \mathrm{C}$ & $6.8 \mathrm{c}$ & $32.5 d$ & $4.41 \mathrm{e}$ \\
\hline Thiophanate-methyl & $16.8 f$ & $40.7 \mathrm{C}$ & $6.2 \mathrm{e}$ & $24.1 \mathrm{~g}$ & $2.63 \mathrm{~g}$ \\
\hline Pathogen only & $15.7 \mathrm{~g}$ & $30.0 \mathrm{~d}$ & $5.2 f$ & $14.8 \mathrm{~h}$ & $2.24 \mathrm{~h}$ \\
\hline
\end{tabular}

The same letter after means in each column is not significantly different according to Duncan's multiple range test $(P=0.05)$

\section{Field experiments}

\section{Effect of Trichoderma spp. and thiophanate-methyl on} disease incidence

The efficacy of soil treatment with Trichoderma spp. and seed coating with thiophanate-methyl individually and/ or combined against damping-off and root rot/wilt diseases of dry bean were evaluated under field conditions. Data in Table 3 clearly demonstrate that all treatments significantly reduced damping-off and root rot/wilt severity compared with the control. Dry bean seed coated with thiophanate-methyl together with soil treatment with Trichoderma spp. were more effective than using either alone. Also, the obtained data show that soil treatment with any of Trichoderma spp. (T. harzianum, T. viride, and $T$. virens) was almost similar to seed coated with thiophanate-methyl in reducing damping-off and root rot/wilt. Thiophanate-methyl $+T$. virens recorded the highest redaction of damping-off and root rot/wilt in both seasons, whereas recorded $92.6 \%$ and $93.0 \%$ survival plants compared with 68.2 and $66.0 \%$ in control plants in both seasons, respectively. In the contrary, the individual treatment with each of $T$. harzianum, $T$. viride, $T$. virens, and thiophanate-methyl were recorded the lowest ones in both seasons $(85.2,85.5,86.4$, and $85.6 \%$ survival plants in first seasons and 85.9, 87.6, 84.4, and $83.2 \%$ in second season, respectively).

\section{Effect of Trichoderma spp. and thiophanate-methyl on growth parameters and yield components}

The effect of soil treatment with each of Trichoderma spp. (T. harzianum, $T$. viride, and $T$. virens) and seed coated with the chemical fungicide (thiophanate-methyl) individually and/or combined on growth parameters and yield components of dry bean under field conditions during seasons 2015 and 2016 were studied. Data in Table 4 indicate that the combination between Trichoderma spp. and thiophanate-methyl significantly improved dry bean growth and yield components more than used individually. Also, soil treated with any of Trichoderma spp. were more effective in this respect than seed coated with the chemical fungicide. The combinations between thiophanate-methyl $+T$. virens were the most effective treatments; they recorded the highest fresh weight of shoot (28.8 and $45.6 \mathrm{~g}$ ) and number of branches (4.2 and 5.2 branch/plant) in both seasons, respectively. Also, this treatment recorded the 
Table 3 Effect of soil application with Trichoderma spp. and seed coating with thiophanate-methyl employed either alone or in combination on damping-off, root rot/wilt, and survival dry bean plants grown under field conditions

\begin{tabular}{|c|c|c|c|c|}
\hline \multirow[t]{3}{*}{ Treatment } & \multicolumn{4}{|l|}{ Season 2015} \\
\hline & \multicolumn{2}{|l|}{ Damping-off (\%) } & \multirow[t]{2}{*}{ Root rot (\%) } & \multirow[t]{2}{*}{ Survival plants (\%) } \\
\hline & Pre-emergence & Post-emergence & & \\
\hline Thiophanate-methyl $+T$. harzianum & $11.7 \mathrm{~cd}$ & $5.7 \mathrm{~b}$ & $3.8 \mathrm{~b}$ & $90.5 \mathrm{ab}$ \\
\hline Thiophanate-methyl $+T$. viride & $10.0 \mathrm{~d}$ & $3.6 \mathrm{~b}$ & $3.6 \mathrm{~b}$ & 92.8 a \\
\hline Thiophanate-methyl $+T$. virens & $10.0 \mathrm{~d}$ & $3.7 \mathrm{~b}$ & $3.7 \mathrm{~b}$ & 92.6 a \\
\hline T. harzianum & $21.7 b$ & $6.4 \mathrm{~b}$ & $8.4 \mathrm{~b}$ & $85.2 \mathrm{~b}$ \\
\hline T. viride & $20.0 \mathrm{bc}$ & $6.3 b$ & $8.2 \mathrm{~b}$ & $85.5 \mathrm{~b}$ \\
\hline T. virens & $26.7 \mathrm{~b}$ & $6.8 \mathrm{~b}$ & $6.8 \mathrm{~b}$ & $86.4 \mathrm{ab}$ \\
\hline Thiophanate-methyl & $18.3 \mathrm{bcd}$ & $6.2 b$ & $8.2 \mathrm{~b}$ & $85.6 \mathrm{~b}$ \\
\hline Control & 36.3 a & $13.4 \mathrm{a}$ & $18.4 \mathrm{a}$ & $68.2 \mathrm{c}$ \\
\hline \multirow[t]{3}{*}{ Treatment } & \multicolumn{4}{|l|}{ Season 2016} \\
\hline & \multicolumn{2}{|l|}{ Damping-off (\%) } & \multirow[t]{2}{*}{ Wilt (\%) } & \multirow[t]{2}{*}{ Survival plants (\%) } \\
\hline & Pre-emergence & Post-emergence & & \\
\hline Thiophanate-methyl $+T$. harzianum & $8.3 \mathrm{~cd}$ & $5.5 \mathrm{~b}$ & $3.6 \mathrm{~b}$ & $90.9 \mathrm{ab}$ \\
\hline Thiophanate-methyl $+T$. viride & $8.3 \mathrm{~cd}$ & $3.6 \mathrm{~b}$ & $3.6 \mathrm{~b}$ & 92.8 a \\
\hline Thiophanate-methyl $+T$. virens & $5.0 \mathrm{~d}$ & $3.5 \mathrm{~b}$ & $3.5 \mathrm{~b}$ & $93.0 \mathrm{a}$ \\
\hline T. harzianum & $18.3 \mathrm{bc}$ & $6.0 \mathrm{~b}$ & $8.1 \mathrm{~b}$ & 85.9 bc \\
\hline T. viride & $18.3 \mathrm{bc}$ & $6.2 \mathrm{~b}$ & $6.2 \mathrm{~b}$ & $87.6 \mathrm{abc}$ \\
\hline T. virens & $25.0 \mathrm{~b}$ & $6.8 \mathrm{~b}$ & $6.8 \mathrm{~b}$ & $84.4 \mathrm{bc}$ \\
\hline Thiophanate-methyl & $21.7 b$ & $8.4 \mathrm{ab}$ & $8.4 \mathrm{~b}$ & $83.2 \mathrm{c}$ \\
\hline Control & $40.0 \mathrm{a}$ & $13.7 \mathrm{a}$ & 19.8 a & $66.5 d$ \\
\hline
\end{tabular}

The same letter after means in each column is not significantly different according to Duncan's multiple range test $(P=0.05)$

highest yield components, i.e., number of pods (9.0 and 12.0 pods/plant), pod weight ( 3.35 and $3.25 \mathrm{~g})$, weight of 100 seeds (44.14 and $50.50 \mathrm{~g}$ ), and weight of seed ( 0.44 and $0.51 \mathrm{~g}$ ) in both seasons, respectively. On the contrary, dry bean seed coated with thiophanate-methyl only was less effective in both seasons compared with the other treatments.

\section{Effect of Trichoderma spp. and thiophanate-methyl on enzymatic activities in dry bean plants grown under field conditions}

The effect of soil treatment with each of Trichoderma spp. (T. harzianum, T. viride, and T. virens) and seed coated with the chemical fungicide (thiophanate-methyl) individually and/or combined on enzyme activities of peroxidase, polyphenoloxidase, and chitinase in dry bean plants grown under field conditions during seasons 2015 and 2016 was studied. Data presented in Table 5 reveal that all treatments were pronounced in the induction of defense enzyme in comparison with the control. Data in Table 5 also reveal that the combination between Trichoderma spp. and thiophanate-methyl significantly induce defense enzymes in bean plants more than used individually. They induced high activation of peroxidase (by 83.3, 83.5, and
$82.9 \%$ and 86.9, 86.4, and $85.7 \%$ increase over control), polyphenoloxidase (by 64.2, 63.9, and $65.6 \%$ and 65.3, 64.8, and $65.0 \%$ increase over control), and chitinase (by 92.4, 91.5, and $91.0 \%$ and 92.1, 91.5, and $91.0 \%$ increase over control) in both seasons, respectively. On the contrary, the individual treatment of T. harzianum, $T$. viride, $T$. virens, and thiophanate-methyl only occupied significantly the second in the induction of these enzymes compared with the control.

\section{Discussion}

In the present study, dry bean seeds coated with thiophanate-methyl combined with Trichoderma spp. soil treatment reduced damping-off and root rot/wilt incidence more than using any of them individually. Data also reveal that Trichoderma spp. were more effective to reduce damping-off and root rot/wilt than thiophanatemethyl. On the other hand, the combination of thiophanate-methyl $+T$. virens, thiophanate-methyl + $T$. harzianum, and thiophanate-methyl $+T$. viride recorded almost the same protection against to any of the tested fungi. It was suggested that the addition of Trichoderma spp. to the soil before sowing reduced the inoculums of the pathogens and bean seeds coated with 
Table 4 Effect of soil application with Trichoderma spp. and seed coating with thiophanate-methyl employed either alone or in combination on growth parameters and yield components of dry bean grown under field condition

\begin{tabular}{|c|c|c|c|c|c|c|}
\hline \multirow{2}{*}{ Treatment } & \multicolumn{6}{|l|}{ Season 2015} \\
\hline & $\begin{array}{l}\text { Shoot fresh } \\
\text { weight }(\mathrm{g})\end{array}$ & No. of Branches/plant & No. of pods/plant & Pod weight (g) & $\begin{array}{l}\text { Weight of } \\
100 \text { seeds (g) }\end{array}$ & Seed weight $(\mathrm{g})$ \\
\hline Thiophanate-methyl $+T$. harzianum & $24.5 \mathrm{ab}$ & $3.6 \mathrm{ab}$ & $6.2 c$ & $2.99 \mathrm{C}$ & $38.40 \mathrm{~d}$ & $0.38 d$ \\
\hline Thiophanate-methyl $+T$. viride & $22.1 \mathrm{ab}$ & $3.4 \mathrm{abc}$ & $8.2 \mathrm{~b}$ & $3.44 \mathrm{~b}$ & $44.16 \mathrm{a}$ & $0.44 a$ \\
\hline Thiophanate-methyl $+T$. virens & $28.8 \mathrm{a}$ & $4.2 \mathrm{a}$ & $9.0 \mathrm{a}$ & $3.35 \mathrm{a}$ & $44.14 \mathrm{a}$ & $0.44 \mathrm{a}$ \\
\hline T. harzianum & $14.0 \mathrm{~cd}$ & $2.2 \mathrm{c}$ & $6.2 c$ & $2.23 \mathrm{f}$ & $34.93 \mathrm{e}$ & 0.35 e \\
\hline T. viride & $20.4 b c$ & $4.0 \mathrm{a}$ & $5.8 \mathrm{c}$ & $2.47 \mathrm{e}$ & $40.35 c$ & $0.40 \mathrm{c}$ \\
\hline T. virens & $21.5 \mathrm{ab}$ & $3.0 \mathrm{abc}$ & $5.8 \mathrm{c}$ & $2.85 d$ & $43.41 \mathrm{~b}$ & $0.43 \mathrm{~b}$ \\
\hline Thiophanate-methyl & $11.8 \mathrm{~d}$ & $2.7 \mathrm{bc}$ & $2.9 \mathrm{~d}$ & $1.88 \mathrm{~g}$ & $31.22 f$ & $0.31 \mathrm{f}$ \\
\hline Control & $10.8 d$ & $2.1 \mathrm{C}$ & $2.7 \mathrm{~d}$ & $1.32 \mathrm{~h}$ & $27.28 \mathrm{~g}$ & $0.27 \mathrm{~g}$ \\
\hline \multirow[t]{2}{*}{ Treatment } & \multicolumn{6}{|l|}{ Season 2016} \\
\hline & $\begin{array}{l}\text { Shoot fresh } \\
\text { weight (g) }\end{array}$ & No. of Branches/plant & No. of pods/plant & Pod weight (g) & $\begin{array}{l}\text { Weight of } \\
100 \text { seeds (g) }\end{array}$ & Seed weight (g) \\
\hline Thiophanate-methyl + T. harzianum & $32.8 b$ & $4.6 \mathrm{ab}$ & $8.8 \mathrm{~b}$ & $3.14 b$ & $43.99 \mathrm{c}$ & $0.44 c$ \\
\hline Thiophanate-methyl $+T$. viride & $37.6 \mathrm{ab}$ & $5.2 \mathrm{a}$ & $9.2 \mathrm{~b}$ & $3.07 \mathrm{c}$ & $50.11 \mathrm{~b}$ & $0.50 \mathrm{~b}$ \\
\hline Thiophanate-methyl $+T$. virens & $45.6 \mathrm{a}$ & $5.2 \mathrm{a}$ & $12.0 \mathrm{a}$ & $3.25 \mathrm{a}$ & $50.50 \mathrm{a}$ & $0.51 \mathrm{a}$ \\
\hline T. harzianum & $17.5 \mathrm{C}$ & $3.4 \mathrm{bcd}$ & $9.1 \mathrm{~b}$ & $1.96 f$ & $37.24 \mathrm{f}$ & 0.37 e \\
\hline T. viride & $18.3 \mathrm{C}$ & $3.0 \mathrm{~cd}$ & $7.6 c$ & $2.58 \mathrm{~d}$ & $41.41 \mathrm{~d}$ & $0.41 \mathrm{~d}$ \\
\hline T. virens & $23.4 \mathrm{C}$ & $4.0 \mathrm{abc}$ & $6.5 d$ & $2.19 \mathrm{e}$ & 38.90 e & $0.39 d$ \\
\hline Thiophanate-methyl & $14.4 \mathrm{C}$ & $2.8 \mathrm{~cd}$ & $2.8 \mathrm{e}$ & $1.99 \mathrm{~g}$ & $30.71 \mathrm{~g}$ & $0.31 \mathrm{f}$ \\
\hline Control & $14.0 \mathrm{C}$ & $2.0 \mathrm{~d}$ & $2.6 \mathrm{e}$ & $1.42 \mathrm{~h}$ & $28.56 \mathrm{~h}$ & $0.29 \mathrm{~g}$ \\
\hline
\end{tabular}

The same letter after means in each column is not significantly different according to Duncan's multiple range test $(P=0.05)$

thiophanate-methyl protect them from invasion by such pathogens. In the previous study, we found that Trichoderma spp. were highly compatible with thiophanate-methyl in vitro tests (Elshahawya et al. 2016). Also, the combined treatment of Trichoderma spp. and thiophanate-methyl highly reduced the growth of $F$. solani and $F$. oxysporum than individual treatment (Elshahawya et al. 2016). Hefnawy et al. (2014) found that $T$. harzianum and T. koningii combined with low dose of Rizolex T 50\% increased the inhibition percentages of pathogenic fungi and may be beneficial in controlling soil-borne fungi. Bhale and Rajkonda (2015) reported that $T$. viride, $T$. harzianum, $T$. koningii, and T. virens were compatible to fungicides viz., Mancozeb and Captan at lower concentrations. Also, Wedajo (2015) reported that by increasing the fungicide concentrations to $400 \mathrm{ppm}$ (sancozeb) and $600 \mathrm{ppm}$ (curzate), T. harzianum and T. viride tolerate the fungicides $50 \%$ and slightly incompatible at higher concentrations of 800 and $1000 \mathrm{ppm}$, and completely inhibited beyond $1000 \mathrm{ppm}$, compared to the control for both fungicides. The obtained results are in agreement with those obtained by many workers. Chaparro et al. (2011) reported that Trichoderma spp. were able to survive in soils with remnants of fungicide molecules such as fungicides of Captan, thiabendazol, and the mixture Captan-Carboxin. Mahmood et al. (2015) reported that thiophanate-methyl combined with Trichoderma spp. gave adequate disease control of bean seedlings and can protecting bean seedling in the field. The use of Trichoderma spp. combined with some commercial fungicides was applied by many workers to obtain additive effects against soil-borne pathogens. Howell et al. (1997) reported that cotton seeds treated with T. virens plus metalaxyl gave seedling stands significantly greater than the untreated seeds as well as seeds treated with fungicide only. Wang et al. (2005) suggested that Trichoderma combined with fludioxonil could be applied into a disease management program for controlling of Fusarium root rot in coneflower. Howell (2007) indicated that Trichoderma spp. plus chloroneb produce the optimum combination treatment for damping-off control of cotton, followed by $T$. virens plus chloroneb plus metalaxyl. Khalequzzaman (2016) showed that seed treatment with Provax $200(2.5 \mathrm{~g} / \mathrm{kg}$ seed), followed by seed treatment with $T$. harzianum compost (1:5) gave the lowest foot and root rot disease incidence of lentil than the untreated control. 
Table 5 Effect of soil application with Trichoderma spp. and seed coating with thiophanate-methyl employed either alone or in combination on the activity of peroxidase, polyphenoloxidase, and chitinase enzymes of dry bean plants grown under field condition

\begin{tabular}{|c|c|c|c|}
\hline \multirow[t]{2}{*}{ Treatment } & \multicolumn{3}{|l|}{ Season 2015} \\
\hline & Peroxidase & Polyphenoloxidase & Chitinase \\
\hline Thiophanate-methyl $+T$. harzianum & $0.968 \mathrm{a}$ & $2.483 \mathrm{~b}$ & $2.272 \mathrm{a}$ \\
\hline Thiophanate-methyl $+T$. viride & $0.984 \mathrm{a}$ & $2.457 \mathrm{~b}$ & $2.047 \mathrm{~b}$ \\
\hline Thiophanate-methyl $+T$. virens & 0.947 a & $2.579 a$ & $1.928 b$ \\
\hline T. harzianum & $0.721 \mathrm{bc}$ & $1.084 \mathrm{C}$ & $1.542 \mathrm{c}$ \\
\hline T. viride & $0.649 \mathrm{~b}$ & $1.062 \mathrm{C}$ & $1.313 d$ \\
\hline T. virens & $0.588 c$ & $1.079 c$ & $1.549 c$ \\
\hline Thiophanate-methyl & $0.581 \mathrm{c}$ & $1.061 \mathrm{c}$ & $1.244 \mathrm{~d}$ \\
\hline Control & $0.162 d$ & $0.888 d$ & 0.173 e \\
\hline \multirow[t]{2}{*}{ Treatment } & \multicolumn{3}{|l|}{ Season 2016} \\
\hline & Peroxidase & Polyphenoloxidase & Chitinase \\
\hline Thiophanate-methyl $+T$. harzianum & $0.976 \mathrm{a}$ & $2.594 \mathrm{a}$ & 2.118 \\
\hline Thiophanate-methyl $+T$. viride & $0.939 a b$ & $2.554 \mathrm{a}$ & 1.975 \\
\hline Thiophanate-methyl $+T$. virens & $0.893 \mathrm{~b}$ & $2.570 \mathrm{a}$ & 1.864 \\
\hline T. harzianum & $0.721 \mathrm{c}$ & $1.069 \mathrm{c}$ & 1.481 \\
\hline T. viride & $0.624 d$ & $1.145 b$ & 1.206 \\
\hline T. virens & 0.490 e & $1.097 \mathrm{bc}$ & 1.621 \\
\hline Thiophanate-methyl & $0.650 d$ & $1.077 \mathrm{c}$ & 1.287 \\
\hline Control & $0.128 \mathrm{f}$ & $0.899 \mathrm{~d}$ & 0.167 \\
\hline
\end{tabular}

The same letter after means in each column is not significantly different according to Duncan's multiple range test $(P=0.05)$

In the present study, under field conditions, data reveal that the combination between Trichoderma spp. and thiophanate-methyl significantly induce the defense enzymes in bean plants more than used individually. A positive correlation between the biocontrol activates of Trichoderma species isolates and enhancement of peroxidase, polyphenoloxidase, and chitinase enzymes in bean plants to resist infection with soil-borne pathogens. The reduction in bean damping-off and root-rot/wilt incidence may be due to an increase in the defense-related enzymes such as peroxidase, polyphenoloxidase, and chitinase. The oxidative enzymes play an important role in induced resistance by the oxidation of phenols to oxidized toxic products (quinine) which limit fungal activity. Peroxidases catalyze a number of reactions that fortify plant cell walls. These reactions include the incorporation of phenolics into cell walls and lignifications and suberization of plant cell walls. On the other hand, the chitinase enzymes play roles in plant defense against fungi by hydrolyzing their cell wall. The amount of them significantly increase and play the main role of defense reaction against fungal pathogen by degrading cell wall, because chitin is a major structural component of the cell walls of many pathogenic fungi. These results also are in agreement with those obtained by Abd-El-Khair et al. (2010) and Abd-El-Khair and El-Gamal Nadia (2011).
In the present study, under greenhouse conditions, Trichoderma spp. combined with thiophanate-methyl were increased vegetative growth parameters of bean plants more than using any of them individually in terms of root length $(\mathrm{cm})$, shoot length $(\mathrm{cm})$, number of leaves/ plant, plant fresh weight (g), and plant dry weight (g). Also, under field conditions, Trichoderma spp. and thiophanate-methyl significantly improve the dry bean growth and yield components more than used individually. It is to be noted that growth promotion effect is one of the mechanisms of Trichoderma spp. exerted for the control of phytopathogenic diseases (Benítez et al. 2004; Sharma et al. 2012; Gajera et al. 2013). The capacity of Trichoderma spp. to promote growth results from the production of phytohormones that promote growth characteristics of the plants. Hexon et al. (2009) described induced production of three auxin-related compounds (indole-3-acetic acid, indole-3-acetaldehyde, and indole3-ethanol) causing the development of Arabidopsis seedlings in response to inoculation with $T$. virens and $T$. atroviride. This was also supported by Harman et al. (2004) who found that Trichoderma spp. colonize root surfaces and penetrate the epidermis before producing or releasing a variety of compounds that induce localized or systemic resistance responses. Therefore, plants become protected from the pathogenic fungus, 
indicating induction of SAR in plants treated with the biological isolates.

\section{Conclusion}

In conclusion, the use of these compatible isolates of Trichoderma spp. as soil treatment combined with the fungicide (thiophanate-methyl) as seed treatment could be recommended for the control of damping-off and root rot/wilt of dry bean.

\section{Acknowledgements}

Not applicable.

\section{Funding}

Not applicable.

\section{Availability of data and materials}

The datasets used and/or analyzed during the current study are available from the corresponding author on reasonable request.

\section{Authors' contributions}

All authors read and approved the final manuscript.

\section{Ethics approval and consent to participate}

Not applicable.

\section{Consent for publication}

Not applicable.

\section{Competing interests}

The authors declare that they have no competing interests.

\section{Publisher's Note}

Springer Nature remains neutral with regard to jurisdictional claims in published maps and institutional affiliations.

\section{Author details}

${ }^{1}$ Plant Pathology Department, Agricultural and Biological Research Division, National Research Centre, Giza, Egypt. ${ }^{2}$ Pest Rearing Department, Central Agricultural Pesticides Laboratory, Agricultural Research Centre, Dokki, Giza, Egypt.

Received: 13 June 2018 Accepted: 24 January 2019

Published online: 04 February 2019

\section{References}

Abdel-Kader MM (1997) Field application of Trichoderma harzianum as biocide for control bean root rot disease. Egypt J Phytopathol 25:19-25

Abd-El-Khair H, El-Gamal Nadia G (2011) Effects of aqueous extracts of some plant species against Fusarium solani and Rhizoctonia solani in Phaseolus vulgaris plants. Arch Phytopathol Plant Protect 44(1):1-16

Abd-El-Khair H, Khalifa RM, Haggag Karima HE (2010) Effect of Trichoderma species on damping off diseases incidence, some plant enzymes activity and nutritional status of bean plants. J Am Sci 6(12):122-134

Bashan Y, Okon Y, Henis Y (1985) Peroxidase, polyphenol oxidase, and phenols in relation to resistance against 214 Pseudomonas syringae $\mathrm{pv}$. tomato in tomato plants. Can J Bot 65:366-372

Benítez T, Rincón AM, Limón MC, Codón AC (2004) Biocontrol mechanisms of Trichoderma strains. Int Microbiol 7:249-260

Bhale UN, Rajkonda JN (2015) Compatibility of fungicides and antagonistic activity of Trichoderma spp. against plant pathogens. Biosci Methods 6(3):1-9

Chaparro A, Carvajal L, Orduz S (2011) Fungicide tolerance of Trichoderma asperelloides and T. harzianum strains. Agric Sci 2:301-307

El-Nagdi WMA, Abd-El-Khair H (2014) Biological control of Meloidogyne incognita and Fusarium solani in dry common bean in the field. Arch Phytopathol Plant Protect 47(4):388-397
Elshahawy IE, Saied N, Abd-El-Kareem F, Morsy A (2017b) Biocontrol of onion white rot by application of Trichoderma species formulated on wheat bran powder. Arch Phytopathol Plant Protect 50(3-4):150-166

Elshahawy IE, Saied N, Abd-El-Kareem F, Morsy A (2017c) Field application of sclerotial mycoparasites as biocontrol agents to Stromatinia cepivora, the cause of onion white rot. J Plant Pathol 99(2):391-401

Elshahawy IE, Saied NM, Morsy AA (2017a) Fusarium proliferatum, the main cause of clove rot during storage, reduces clove germination and causes wilt of established garlic plants. J Plant Pathol 99(1):81-89

Elshahawya IE, Haggag K, Abd-El-Khair H (2016) Compatibility of Trichoderma spp. with seven chemical fungicides used in the control of soil borne plant pathogens. Research Journal of Pharmaceutical, Biological and Chemical Sciences 7(1):1772-1785

Estevez de Jensen C, Meronuck R, Percich JA (1999) Bocontrol of kidney bean root rot in Minnesota. Phytopathology S24(Abstr):89

Estevez de Jensen C, Percich JA, Graham PH (2002) Integrated management strategies of bean root rot with Bacillus subtilis and Rhizobium in Minnesota. Field Crop Res 74:107-115

Gajera H, Domadiya R, Patel S, Kapopara M, Golakiya B (2013) Molecular mechanism of Trichoderma as bio-control agents against phytopathogen system-a review. Curr Res Microbiol Biotechnol 1:133-142

Hammerschmidt R, Lamport DTA, Muldoon EP (1984) Cell wall hydroxyproline enhancement and lignin deposition as an early event in the resistance of cucumber to Cladosporium cucumerinum. Physiol Plant Pathol 24:43-47

Harman GE, Howell CR, Viterbo A, Chet I, Lorito M (2004) Trichoderma speciesopportunistic, virulent plant symbionts. Nat Rev Microbiol 2:43-56

Hefnawy MA, Eisa Omima A, El-Feky Nora M (2014) Impact of the fungicide Rizolix T50\% on the antagonistic activity of Trichoderma harzianum and Trichoderma koningii. Int J Sci Res 3(9):1767-1773

Hexon C, Macias-Rodriguez L, Cortes-Penagos C, López-Bucio J (2009) Trichoderma virens, a plant beneficial fungus, enhances biomass production and promotes lateral root growth through an auxin-dependent mechanism in Arabidopsis. Plant Physiol 149:1579-1592

Howell CR (2007) Effect of seed quality and combination fungicide-Trichoderma spp. seed treatments on pre- and post-emergence damping off in cotton. Phytopathology 97:66-71

Howell CR, DeVay JE, Garber RH, Batson WE (1997) Field control of cotton seedling diseases with Trichoderma virens in combination with fungicide seed treatments. J Cotton Sci 1:15-20

Khalequzzaman KM (2016) Control of foot and root rot of lentil by using different management tools. ABC J Adv Res 5(1):35-42

Lee $T$ (1973) On extraction and quantitation of plant peroxidase isoenzymes. Physiol Plant 29:198-203

Mahmood Y, Khan MA, Javed N, Arif MJ (2015) Comparative efficacy of fungicides and biological control agents for the management of chickpea wilt caused by Fusarium oxysporum f. sp. ciceris. J Anim Plant Sci 25(4):1063-1071

Monreal J, Reese ET (1969) The chitinase of Serratia marcescens. Can J Microbiol 15:689-696

Sharma R, Joshi A, Dhaker RC (2012) A brief review on mechanism of Trichoderma fungus use as biological control agents. Int J Biosci 2:200-210

Singleton L, Mihail J, Rush C (1992) Methods for research on soil-borne phytopathogenic fungi. The American Phytopathological Society, St. Paul

Steel RGD, Torrie TH (1980) Principles and procedures of statistics. McGraw- Hill Book Company Inc., New York

Vasundara P, Rangaswamy V, Johnson M (2015) Compatibility studies with fungicides, insecticides and their combinations on Trichoderma viridae in vitro conditions. Int J Sci Eng Res 6(2):310-316

Wang H, Chang KF, Hwang SF, Turnbull GD, Howard RJ, Blade SF, Callan NW (2005) Fusarium root rot of coneflower seedlings and integrated control using Trichoderma and fungicides. BioControl 50(2):317-329

Wedajo B (2015) Compatibility studies of fungicides with combination of Trichoderma species under in vitro conditions. Virol Mycol 4:149. https://doi. org/10.4172/2161-0517.1000149

Woo SL, Ruocco M, Vinale F, Nigro M, Marra R, Lombardi N, Pascale A, Lanzuise S, Manganiello G, Lorito MM (2014) Trichoderma-based products and their widespread use in agriculture. Open Mycol J 8:71-126 